\title{
Response to: Flavia Magazoni Gonçalves, Marcello Rizzatti Luizon, Jose G. Speciali: "Haplotypes in candidate genes related to nitric oxide pathways and vascular permeability associated with migraine with aura"
}

\author{
Markus Schürks
}

Received: 12 March 2012/Accepted: 22 March 2012/Published online: 12 April 2012

(C) The Author(s) 2012. This article is published with open access at Springerlink.com

Migraine is regarded as a "neurovascular disorder" presenting with dysfunctions of both the brain and the vascular system. However, the initial spark causing migraine appears to be generated within the brain, which is supported by results from recent genome-wide association studies (GWAS) [1, 2], while vascular phenomena are likely epiphenomena [3]. In addition, migraine with aura has been associated with an increased risk for ischemic stroke, while such an association is less clear for other vascular disorders [4]. In contrast, migraine without aura, which is far more common than migraine with aura, does not seem to carry an increased risk for vascular disease.

So, how are the brain and the vasculature linked in migraine? The short answer is: We do not really know. A longer answer would first have to state that the link is likely complex and may include shared genetics. One approach to decipher this link is to investigate variants in genes involved in vascular tone control, including genes coding for the nitric oxide synthases (NOS), a family of enzymes found in the nervous system, cardiovascular system, and endothelium [5]. Results at the single variant level from studies investigating NOS2 and NOS3 genes [6-11] as well as the vascular endothelial growth factor (VEGF) gene [12] in migraine did not give a clear answer. Reasons may include the wide phenotypic spectrum of migraine, differences in study design, genetically heterogeneous populations, and limited sample sizes. Analyses utilizing the integrated information from multiple gene variants such as haplotype analyses may be beneficial as suggested by recent studies [10-12]. However, it also has to be taken into consideration that studies

M. Schürks $(\bowtie)$

Department of Neurology, University Hospital Essen,

Hufelandstrasse 55, 45122 Essen, Germany

e-mail: markus.schuerks@uni-due.de using even more comprehensive and more efficient approaches like GWAS failed to identify any vascularrelated genes among migraineurs $[1,2,13]$.

What we have learned from studying migraine genetics so far? First, migraine is clinically and genetically heterogeneous making it notoriously difficult to identify susceptibility genes. Any susceptibility gene variant will modify the risk for migraine to only a small to moderate degree; hence, large studies are needed to detect them. Second, any association found — whatever study design used — must be replicated in independent samples/cohorts to make us confident that the associations seen are true and not spurious. Third, novel ways of analyses, for example, investigating the interaction of gene variants may help to understand why and how certain variants influence migraine pathophysiology. However, in order to avoid spurious results interaction analyses should only be performed among gene variants for which there is strong evidence of an association with migraine and if there is enough power to really detect potential interactions.

Conflict of interest Dr. Schürks has received an investigator-initiated research grant from the Migraine Research Foundation. He has received honoraria from L.E.K. Consulting for telephone surveys and from the American Academy of Neurology for educational material. $\mathrm{He}$ is a full-time employee of Bayer HealthCare Germany. None of these disclosures represent a conflict of interest.

Open Access This article is distributed under the terms of the Creative Commons Attribution License which permits any use, distribution, and reproduction in any medium, provided the original author(s) and the source are credited.

\section{References}

1. Anttila V, Stefansson H, Kallela M, Todt U, Terwindt GM, Calafato MS, Nyholt DR, Dimas AS, Freilinger T, Muller- 
Myhsok B, Artto V, Inouye M, Alakurtti K, Kaunisto MA, Hamalainen E, de Vries B, Stam AH, Weller CM, Heinze A, Heinze-Kuhn K, Goebel I, Borck G, Gobel H, Steinberg S, Wolf C, Bjornsson A, Gudmundsson G, Kirchmann M, Hauge A, Werge T, Schoenen J, Eriksson JG, Hagen K, Stovner L, Wichmann HE, Meitinger T, Alexander M, Moebus S, Schreiber S, Aulchenko YS, Breteler MM, Uitterlinden AG, Hofman A, van Duijn CM, Tikka-Kleemola P, Vepsalainen S, Lucae S, Tozzi F, Muglia P, Barrett J, Kaprio J, Farkkila M, Peltonen L, Stefansson K, Zwart JA, Ferrari MD, Olesen J, Daly M, Wessman M, van den Maagdenberg AM, Dichgans M, Kubisch C, Dermitzakis ET, Frants RR, Palotie A, International Headache Genetics C (2010) Genome-wide association study of migraine implicates a common susceptibility variant on 8q22.1. Nat Genet 42(10):869-873

2. Chasman DI, Schürks M, Anttila V, de Vries B, Schminke U, Launer LJ, Terwindt GM, van den Maagdenberg AM, Fendrich K, Volzke H, Ernst F, Griffiths LR, Buring JE, Kallela M, Freilinger T, Kubisch C, Ridker PM, Palotie A, Ferrari MD, Hoffmann W, Zee RY, Kurth T (2011) Genome-wide association study reveals three susceptibility loci for common migraine in the general population. Nat Genet 43(7):695-698

3. Goadsby PJ (2009) The vascular theory of migraine: a great story wrecked by the facts. Brain 132(Pt 1):6-7

4. Schürks M, Rist PM, Bigal ME, Buring JE, Lipton RB, Kurth T (2009) Migraine and cardiovascular disease: a systematic review and meta-analysis. BMJ 339:b3914

5. Goncalves FM, Luizon MR, Speciali JG (2012) Haplotypes in candidate genes related to nitric oxide pathway and vascular permeability associated with migraine and aura. J Headache Pain. doi:10.1007/s10194-012-0438-5

6. Griffiths LR, Nyholt DR, Curtain RP, Goadsby PJ, Brimage PJ (1997) Migraine association and linkage studies of an endothelial nitric oxide synthase (NOS3) gene polymorphism. Neurology 49(2):614-617
7. Borroni B, Rao R, Liberini P, Venturelli E, Cossandi M, Archetti S, Caimi L, Padovani A (2006) Endothelial nitric oxide synthase (Glu298Asp) polymorphism is an independent risk factor for migraine with aura. Headache 46(10):1575-1579

8. Lea RA, Curtain RP, Shepherd AG, Brimage PJ, Griffiths LR (2001) No evidence for involvement of the human inducible nitric oxide synthase (iNOS) gene in susceptibility to typical migraine. Am J Med Genet 105(1):110-113

9. Jia S, Ni J, Chen S, Jiang Y, Dong W, Gao Y (2011) Association of the pentanucleotide repeat polymorphism in NOS2 promoter region with susceptibility to migraine in a Chinese population. DNA Cell Biol 30(2):117-122

10. Goncalves FM, Martins-Oliveira A, Speciali JG, Luizon MR, Izidoro-Toledo TC, Silva PS, Dach F, Tanus-Santos JE (2011) Endothelial nitric oxide synthase haplotypes associated with aura in patients with migraine. DNA Cell Biol 30(6):363-369

11. Mansur TOS, Goncalves FM, Martins-Oliveira A, Speciali JG, Dach F, Lacchini R, Tanus-Santos JE (2012) Inducible nitric oxide synthase haplotype associated with migraine and aura. Mol Cell Biochem. doi:10.1007/s11010-11012-11231-11010

12. Goncalves FM, Martins-Oliveira A, Speciali JG, Izidoro-Toledo TC, Luizon MR, Dach F, Tanus-Santos JE (2010) Vascular endothelial growth factor genetic polymorphisms and haplotypes in women with migraine. DNA Cell Biol 29(7):357-362

13. Ligthart L, de Vries B, Smith AV, Ikram MA, Amin N, Hottenga JJ, Koelewijn SC, Kattenberg VM, de Moor MH, Janssens AC, Aulchenko YS, Oostra BA, de Geus EJ, Smit JH, Zitman FG, Uitterlinden AG, Hofman A, Willemsen G, Nyholt DR, Montgomery GW, Terwindt GM, Gudnason V, Penninx BW, Breteler M, Ferrari MD, Launer LJ, van Duijn CM, van den Maagdenberg AM, Boomsma DI (2011) Meta-analysis of genome-wide association for migraine in six population-based European cohorts. Eur J Hum Genet 19(8):901-907 